\title{
Let me sleep on it: delay reduces rejection rates in Ultimatum Games
}

Citation for published version (APA):

Grimm, V., \& Mengel, F. (2010). Let me sleep on it: delay reduces rejection rates in Ultimatum Games. METEOR, Maastricht University School of Business and Economics. METEOR Research Memorandum No. 017 https://doi.org/10.26481/umamet.2010017

Document status and date:

Published: 01/01/2010

DOI:

10.26481/umamet.2010017

Document Version:

Publisher's PDF, also known as Version of record

\section{Please check the document version of this publication:}

- A submitted manuscript is the version of the article upon submission and before peer-review. There can be important differences between the submitted version and the official published version of record.

People interested in the research are advised to contact the author for the final version of the publication, or visit the DOI to the publisher's website.

- The final author version and the galley proof are versions of the publication after peer review.

- The final published version features the final layout of the paper including the volume, issue and page numbers.

Link to publication

\footnotetext{
General rights rights.

- You may freely distribute the URL identifying the publication in the public portal. please follow below link for the End User Agreement:

www.umlib.nl/taverne-license

Take down policy

If you believe that this document breaches copyright please contact us at:

repository@maastrichtuniversity.nl

providing details and we will investigate your claim.
}

Copyright and moral rights for the publications made accessible in the public portal are retained by the authors and/or other copyright owners and it is a condition of accessing publications that users recognise and abide by the legal requirements associated with these

- Users may download and print one copy of any publication from the public portal for the purpose of private study or research.

- You may not further distribute the material or use it for any profit-making activity or commercial gain

If the publication is distributed under the terms of Article $25 \mathrm{fa}$ of the Dutch Copyright Act, indicated by the "Taverne" license above, 


\section{Maastricht University}

Veronika Grimm, Friederike Mengel

Let me sleep on it: Delay reduces rejection rates in Ultimatum Games

$\mathrm{RM} / 10 / 017$

\section{METEOR}

Maastricht University School of Business and Economics

Maastricht Research School of Economics

of Technology and Organization

\section{PO. Box 616}

NL - 6200 MD Maastricht

The Netherlands 


\title{
Let me sleep on it: Delay reduces rejection rates in Ultimatum Games
}

\author{
Veronika Grimm* $\quad$ Friederike Mengel ${ }^{\dagger}$
}

March 5, 2010

\begin{abstract}
We show that delaying acceptance decisions in the Ultimatum Game drastically increases acceptance rates of low offers. While in standard treatments without delay less than $20 \%$ of low offers are accepted, these numbers increase to around $65-75 \%$ as we delay the acceptance decisions by around 10 minutes. Our findings provide precise evidence for familiar notions such as 'sleeping on it' and show that there may be a good reason why public administrations often communicate bad news on Friday afternoons. They shed new light on recent evidence in Neuroscience on brain activation after receiving bad news and raise questions about the extent to which decisions reveal the preferences of a decision-maker.
\end{abstract}

There is a common implicit understanding that delaying a reaction to bad news may lead to more moderate reactions and hence more prudent economic decisions. This is often alluded to when people say "Let me sleep on it before I make a decision". Public administrations sometimes try to make use of this by communicating bad news on Friday afternoons such that people cannot react until Monday morning. In this study we show that "having a break" can be enough. Delaying decisions by only 10 minutes after receiving bad news drastically changes human behavior in a controlled laboratory environment.

We study the effect of delaying decisions in the context of the so called Ultimatum Game. In this game a proposer proposes a division of say 10 Euros to a responder. If the responder accepts the proposal, both parties receive the suggested amounts. If he rejects both receive nothing. This game has been widely studied to investigate economic decision making and one of the most robust findings in experimental economics is that low offers (of say 1 or 2 Euros) are almost always rejected. Those empirical observations have triggered the development of a literature questioning the standard model of economic decision making which predicts that responders should accept any amount offered and consequently, proposers should never offer more than the minimal amount possible. By now a large body of work exists that incorporates social motives into the description of preferences in order to accommodate the observed behavior (see [3], or [2] for a survey).

In this study we show that the mere fact of delaying the acceptance decision by approximately 10 minutes drastically and significantly changes human behavior in the Ultimatum Game. Acceptance rates for low offers increase from $0-15 \%$ without delay to around $65-75 \%$ with delay.

We report the findings from an experiment held with 168 undergraduate students from Maastricht University (84 per treatment). In each experimental session participants were randomly matched in pairs and given either the role of proposer or responder. The proposer then decided how to split 10 Euros between

\footnotetext{
${ }^{*}$ University of Erlangen-Nuremberg, Department of Economics, Lange Gasse 20, D-90403 Nürnberg, Germany, Tel: +49911-5302 224; Fax: +49-911-5302 168; E-mail: veronika.grimm@wiso.uni-erlangen.de

${ }^{\dagger}$ Department of Economics (AE1), Maastricht University, PO Box 616, 6200 MD Maastricht, The Netherlands; Tel:+31-43-38 83891; Fax:+31-43-38 84878; E-mail: f.mengel@maastrichtuniversity.nl
} 
herself and the responder. This proposal was immediately presented to the responder on her computer screen. In the treatments without delay the responder could decide on the proposal immediately after receiving it. Afterwards all participants filled in a questionnaire which lasted for approximately 10 minutes. In the treatments with delay this order was reversed. All responders first observed the proposal, then filled in the questionnaire, and only thereafter they could decide on the proposal. Hence, their acceptance decision was delayed in a natural way by approximately 10 minutes. The average (minimal, maximal) waiting time was 10:14 (8:40, 11:57) minutes. We used three very different questionnaires and do not find any effect of the questions themselves on responder behavior.

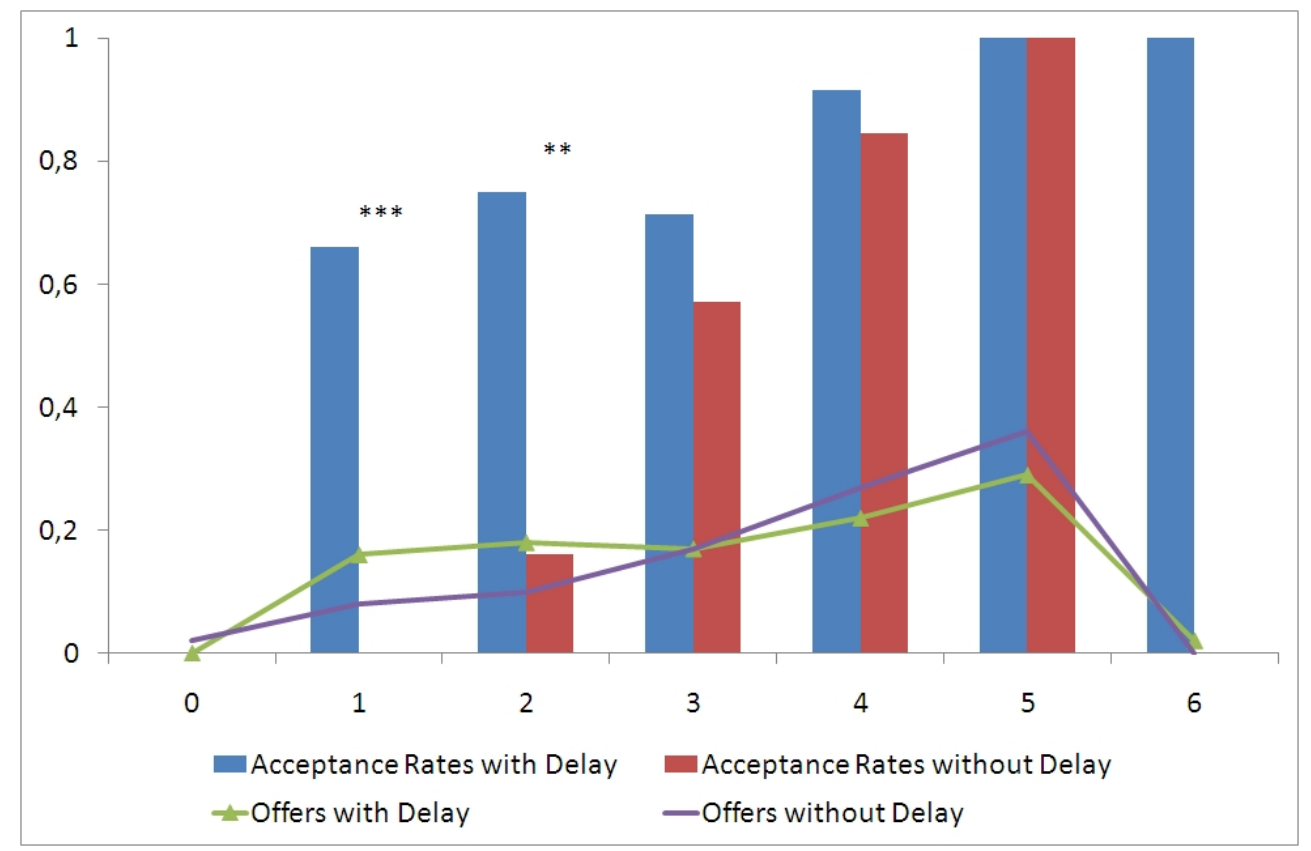

Figure 1: Acceptance Rates and Distributions of Offers. The blue (left) bars indicate the acceptance rates in the treatments with delay and the red (right) bars those in the treatments without delay. $66 \%$ of offers of 1 Euro are accepted with delay and no such offers are accepted without delay. Offers of 2 Euros are accepted by $75 \%$ with delay but only by $16 \%$ without delay. The acceptance rates are significantly different across treatments for offers of 1 and 2 , but not for higher offers (Mann-Whitney, $p=0.0068, p=0.0483, p>0.1205$ ). Also the probability that any 'low' offer is rejected (of 0,1 or 2 ) differs significantly across treatments (Mann-Whitney, $p=0.0008$ ). The distributions of offers in the two treatments are shown by the green and purple lines. The share of extremely low offers of 0 or 1 (those predicted by rationality) differs somewhat between the two treatments (Mann-Whitney, $p=0.0595$ ).

The effect of the delay, though, is drastic, as Figure 1 illustrates. While almost no low offers are accepted without delay, a large share (65-75\%) of these offers gets accepted after a 10 minutes delay only. The fact that offers are somewhat lower with delay could indicate that proposers do anticipate higher acceptance rates to some extent if they know that the acceptance decision will be delayed. In fact, given the acceptance rates we observe proposers maximize their expected payoff by offering 1 in the treatments with delay and 5 in the treatments without delay. Responders in the treatments with delay also earn higher payoffs on average than those in treatments without delay, albeit not significantly so.

Our findings raise fundamental questions about the relation of decisions and underlying preferences. If (more reflected) decisions after delay reveal true preferences, the question arises why (without facing any time pressure) people choose to make different short run decisions and what these decisions reflect. If we want to think of both decisions (with and without delay) as revealing preferences, our results suggest that we 
have to rethink our model of preferences to understand how preferences are formed and why one motivation may come to dominate others to trigger fundamentally different behavior.

Neuroeconomic studies can potentially shed some light on these issues. In fact our results can be useful to distinguish between two hypotheses recently advanced in this literature. In some studies it has been shown that rejections of low offers in the Ultimatum Game are strongly correlated with activation of brain regions such as anterior insula, often associated with feelings such as disgust or anger. These studies also show differential activation of the bilateral DLPFC (dorsolateral prefrontal cortex). A common interpretation is that DLPFC activation might represent cognitive control of the emotional impulse to reject low offers. Other studies, however, have argued the opposite, namely that the DLPFC may be involved in controlling the impulse to accept low offers, i.e. in controlling economic self-interest (see [4], or [1] for a survey). Our results are in line with the former hypothesis, since rejections become much less frequent as the decision maker is forced to delay her reaction.

\section{References}

[1] Camerer, C. and E. Fehr (2007), Social Neuroeconomics: the neural circuitry of social preferences, TRENDS in Cognitive Sciences 11, 419-426.

[2] Cooper, D.J. and J.H. Kagel (2009), Other Regarding Preferences: A Selective Survey of Experimental Results, prepared for the Handbook of Experimental Economics.

[3] Nowak, M., K.M. Page and K. Sigmund (2000), Fairness vs Reason in the Ultimatum Game, Science 289, 1773-1775.

[4] Sanfey, A., J.K. Rilling, J.A. Aronson, L.E. Nystrom and J.D. Cohen (2003), The Neural Basis of Economic Decision-Making in the Ultimatum Game, Science 300, 1755-1758. 


\section{A Supplementary Material}

\section{A.1 Experimental Instructions}

Welcome and thanks for participating in this experiment. Please read these instructions carefully. They are identical for all the participants with whom you will interact during this experiment.

If you have any questions please raise your hand. One of the experimenters will come to you and answer your questions. From now on communication with other participants is not allowed. If you do not conform to these rules we have to exclude you from the experiment. Please do also switch off your mobile phone at this moment.

For your participation you will receive 6 Euros. During the experiment you can earn more. How much depends on your behavior and the behavior of the other participants. All your decisions will be treated confidentially.

\section{THE EXPERIMENT}

At the beginning of the experiment you will be randomly matched with another participant, who we will call your interaction partner.

There are two types of players in the experiment, Player 1 and Player 2. Your role and the role of your interaction partner will be determined by a random draw. In particular, this means that both, you and your interaction partner, will be Player 1 with probability $\frac{1}{2}$.

The experiment has three stages

Stage 1: Player 1 makes an offer how to split 10 Euros among the two of you and Player 2 observes the offer that player 1 has made.

Stage 2: All participants answer a questionnaire which lasts for approximately 10 minutes.

Stage 3: Player 2 can decide whether to accept or reject the offer made by Player 1. If Player 2 accepts, then the money is divided as proposed by player 1. If Player 2 rejects both Players receive 0 Euros.

After Stage 3 the experiment ends.

[In the treatment without delay stage 2 and stage 3 were reversed. Otherwise the instructions were identical.]

\section{A.2 Additional Results and Procedures}

We used three different questionnaires to control for possible effects of the questions themselves on responder behavior. Our first questionnaire (Q1) was 'neutral' asking questions such as "What is your favorite colour?". Our second questionnaire (Q2) was 'cognitive'. Questions in this questionnaire are similar to those that can typically be found in intelligence tests. The third questionnaire (Q3) was 'social' asking participants their opinion about social justice. 
In each session $1 / 3$ of all participants were randomly allocated a questionnaire and the waiting time was the longest time any participant needed to fill in the questionnaire. Hence we ruled out by design that waiting time is correlated with the type of questionnaire the participants filled in.

The following figure shows the acceptance rates as well as the distributions of offers separately for each questionnaire in the treatment with delay. As expected there are no statistically significant differences in the distribution of offers (at the time of making an offer the proposers did not know which questionnaire they, or the responders, had to fill in). Also the distribution of acceptance rates does not differ significantly. Note that in order to calculate overall acceptance rates (Figure 1 in the paper) one needs to take a weighted average over the three bars in the graph, since offers were not distributed equally across treatments.

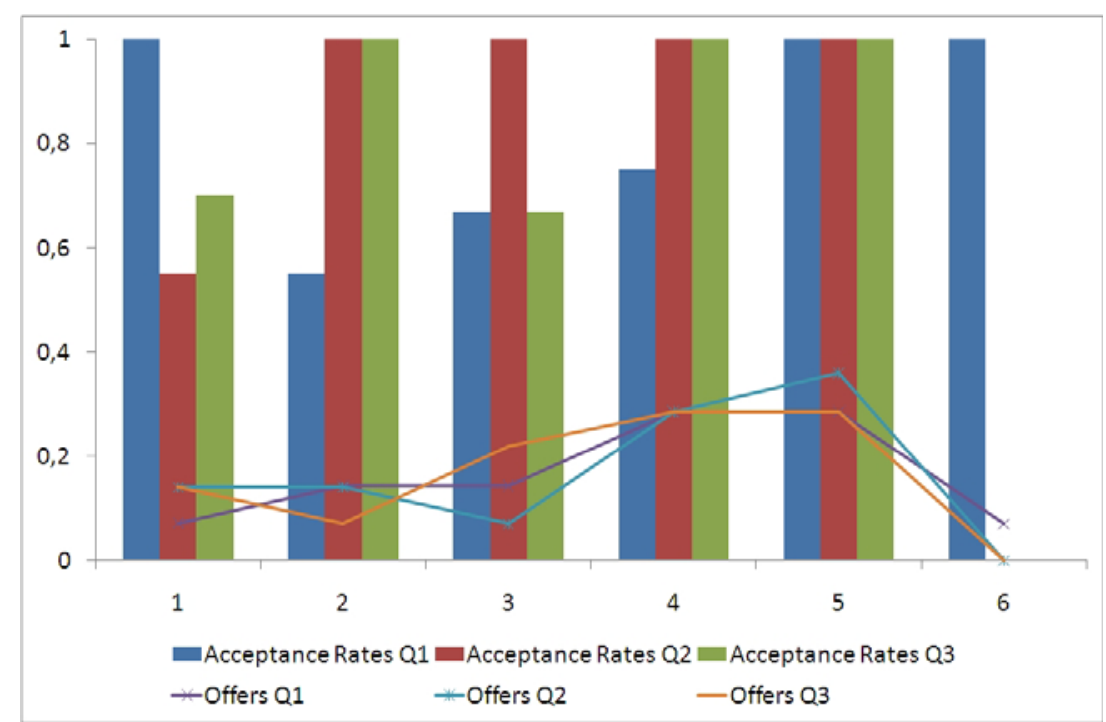

Figure 2: Acceptance Rates and Distributions of Offers per Questionnaire (Q1,Q2 and Q3) with Delay 